\title{
CYP26B1 wt Allele
}

National Cancer Institute

\section{Source}

National Cancer Institute. CYP26B1 wt Allele. NCI Thesaurus. Code C104875.

Human CYP26B1 wild-type allele is located in the vicinity of 2p13.2 and is approximately $19 \mathrm{~kb}$ in length. This allele, which encodes cytochrome P450 26B1 protein, is involved in the specific inactivation of all-trans-retinoic acid. Mutations in this gene are associated with craniofacial and other skeletal anomalies. 